\title{
PEMERIKSAAN GOLONGAN DARAH DALAM RANGKA HARI KARTINI DI STIKES BORNEO CENDEKIA MEDIKA \\ ${ }^{1}$ FEBRI NUR NGAZIZAH
}

${ }^{1}$ Stikes Borneo Cendekia Medika Pangkalan Bun

${ }^{1}$ Email: febrinurngazizah@gmail.com

Abstrak

Darah merupakan cairan tubuh terdapat di dalam sistem peredaran darah tertutup dan sangat penting untuk kelangsungan hidup manusia. Pemeriksaan golongan darah ABO dilakukan untuk menentukan jenis golongan darah pada manusia. Penentuan golongan darah ABO pada umumnya dengan menggunakan metode Slide. Metode ini didasarkan pada prinsip reaksi antara aglutinogen (antigen) pada permukaan eritrosit dengan aglutinin yang terdapat dalam serum/plasma yang membentuk aglutinasi atau gumpalan . Kegiatan pengabdian masyarakat ini bertujuan untuk mengetahui golongan darah mahasiswa Stikes Borneo Cendekia Medika. Dari data hasil menunjukkan pemeriksaan golongan darah menggunakan serum sebagai reagen pada golongan darah A didapatkan hasil positif pada jenis kelamin lakilaki 16 orang sedangkan jenis kelamin perempuan 9 orang. Golongan darah B didapatkan hasil positif pada jenis kelamin laki-laki 26 orang sedangkan jenis kelamin perempuan 18 orang. Golongan darah $\mathrm{AB}$ didapatkan hasil positif pada jenis kelamin laki-laki 10 orang sedangkan jenis kelamin perempuan 12 orang, kemudian Golongan darah O didapatkan hasil positif pada jenis kelamin laki-laki 14 orang sedangkan jenis kelamin perempuan 19 orang.

Kata Kunci: golongan darah, aglutinasi, ABO

\begin{abstract}
Blood is a bodily fluid contained in a closed circulatory system and is essential for human survival. ABO blood type checks are performed to determine the type of blood type in humans. Determination of ABO blood type in general by using the Slide method. This method is based on the principle of the reaction between agglutinogen (antigen) on the surface of erythrocytes with agglutinin contained in the serum / plasma that forms agglutination or lumps. This community service activity aims to find out the blood type of students of Stikes Borneo Scholar Medika. From the data the results show that blood type examination using serum as a reagent in blood type A obtained positive results in the male
\end{abstract}


sex of 16 people while the female sex of 9 people. Blood type B obtained positive results in the male sex of 26 people while the female sex of 18 people. Blood type AB obtained positive results on the male sex of 10 people while the female sex of 12 people, then blood type $\mathrm{O}$ obtained positive results on the male sex of 14 people while the female sex of 19 people.

Keywords: blood type, agglutination, ABO

\section{PENDAHULUAN}

Pengabdian kepada masyarakat mempunyai landasan terhadap konsep bahwa disamping memiliki kemampuan intelektual/akademik sekaligus sebagai makhluk sosial yang memperhatikan lingkungan kehidupan masyarakan dan juga peduli terhadap sesama makhluk hidup.

Pengabdian ke masyarakat merupakan kegiatan yang dilakukan baik individu, kelompok atau bersama-sama untuk membantu masyarakat sesuai dengan visi dan misi yang diembannya, baik berupa pengalaman ilmu pengetahuan, teknologi, seni maupun kesehatan yang langsung dilaksanakan ke masyarakat secara institusional dan profesional sebagai salah satu tugas tanggung jawab terhadap perguruan tinggi. Kegiatan pengabdian masyarakan yang dilakukan STIKes Borneo Cendekia Medika Pangkalan Bun yaitu dalam rangka kegiatan berbuka puasa selain itu juga ada kegiatan pemeriksaan gratis golongan darah.

Darah merupakan cairan tubuh terdapat di dalam sistem peredaran darah tertutup dan sangat penting untuk kelangsungan hidup manusia. Darah berfungsi memasukkan oksigen dan bahan makanan keseluruh tubuh serta mengambil karbon dioksida dan metabolik dari jaringan. Mengetahui golongan darah seseorang sangat penting di ketahui untuk kepentingan medis yaitu salah satunya untuk transfus (Fitri., 2007).

Secara umum darah memiliki 4 golongan yaitu: golongan darah A dimana golongan darah $\mathrm{A}$ mempunyai antigen $\mathrm{A}$ dan anti - B, golongan darah B yaitu golongan darah yang memiliki antigen $\mathrm{B}$ dan anti - A, golongan darah $\mathrm{O}$ golongan darah yang memiliki antibodi tetapi tidak memiliki antigen, dan golongan darah $\mathrm{AB}$ golongan darah yang memiliki antigen tetapi tidak memiliki antibodi (Guyton dan Arthur., 1997). 
Pemeriksaan golongan darah $\mathrm{ABO}$ dilakukan untuk menentukan jenis golongan darah pada manusia. Penentuan golongan darah ABO pada umumnya dengan menggunakan metode Slide. Metode ini didasarkan pada prinsip reaksi antara aglutinogen (antigen) pada permukaan eritrosit dengan aglutinin yang terdapat dalam serum/plasma yang membentuk aglutinasi atau gumpalan. Metode slide merupakan salah satu metode yang sederhana, cepat dan mudah untuk pemeriksaan golongan darah (Sasmita., 2008). Berdasarkan latar belakang di atas, peneliti melakukan penelitian tentang Pemeriksaan Golongan Darah Dengan Reagen Serum Golongan Darah A, B, AB dan O Metode Slide.

\section{Metodelogi}

\section{Alat dan Bahan}

Kapas, Alkohol 70\%, Batang pengaduk,

Blood lanset, Darah, Reagen A,B, O,

Kartu golongan darah,Tisu

\section{Cara Kerja}

1. Siapkan alat dan bahan yang digunakan untuk melakukan pemeriksaan asam urat.

2. Bersihkan ujung jari dengan menggunakan alkohol 70\%.

3. Tusuk ujung jari dengan blood lanset steril.
4. Buang darah pertama dengan menggunakan tisu, lalu teteskan darah pada kartu golongan darah.

5. Diberi setetes reagen golongan darah $\mathrm{A}, \mathrm{B}, \mathrm{AB}$ dan $\mathrm{O}$ pada sisi tengah tetesan darah.

6. Diaduk tetesan masing - masing serum dengan darah tersebut menggunakan batang pengaduk steril.

7. Setelah selesai melakukan pemeriksaan cabut jarumnya dari lancing dan dibuang.

8. Chip di buang ke Disposafe box

9. Tutup rapat botol strip apabila tidak dipakai.

\section{HASIL DAN PEMBAHASAN}

Tabel 1. Distribusi frekuensi kategori pemeriksaan golongan darah

\begin{tabular}{cccc}
\hline \multirow{2}{*}{$\begin{array}{c}\text { Golongan } \\
\text { darah }\end{array}$} & \multicolumn{2}{l}{ Kenis } & \\
\cline { 2 - 3 } & $\mathrm{L}$ & $\mathrm{P}$ & \\
\hline $\mathrm{A}$ & 16 & 9 & 25 \\
$\mathrm{~B}$ & 26 & 18 & 44 \\
$\mathrm{AB}$ & 10 & 12 & 22 \\
$\mathrm{O}$ & 14 & 19 & 33 \\
\hline Total & 66 & 58 & 124 \\
\hline
\end{tabular}

Berdasarkan hasil pemeriksaan pada kegiatan dalam rangka Hari Kartini di STIKes Borneo Cendekia Medika berdasarkan sistem golongan darah A,B, $\mathrm{AB}$ dan $\mathrm{O}$ yang digunakan reagen anti $\mathrm{A}$, anti $\mathrm{B}$, anti $\mathrm{AB}$ dan Anti $\mathrm{O}$ yaitu sebagai pembanding. Pada prinsipnya pemeriksaan 
golongan darah yaitu antigen dan antibodi dimana serum terdapat antibodi karena antibodi golongan darah merupakan protein globulin, yang bertanggung jawab sebagai kekebalan tubuh alamiah (Gandasoebrata., 2004).

Aglutinasi dapat terjadi, karena di eritrosit terdapat antigen $\alpha$ dan antigen $\beta$. Antigen ini akan bereeaksi dengan antibodi yang ada didalam serum. Setiap golongan darah memiliki struktur antigen dimana struktur tersebut berfungsi untuk membedakan darah (Guyton dan Arthur., 1997).

Antingen adalah sebuah zat yang menstimulasi tanggapan imun, terutama dalam produksi antibodi. Antingen biasanya berupa protein atau polisarida, tetapi dapat juga berupa molekul lainnya, termasuk molekul kecil dipasangkan dengan protein pembawa. Anti gen ini dibagi menjadi anti gen $\mathrm{A}$ dan anti gen $\mathrm{B}$. dimana anti gen A hanya terdapat dan dihasilkan pada seseorang bergolongan darah $\mathrm{A}$ dan $\mathrm{O}$, sedangkan anti gen $\mathrm{B}$ hanya terdapat pada seseorang bergolongan darah B dan O. Serum adalah zat anti yang disebut sebagai antibodi atau agglutinin yang dihasilkan di dalam sel darahnya, sehingga yang disebut dengan anti serum adalah zat anti atau agglutinin yang tidak dihasilkan seseorang di dalam sel darahnya (Gandasoebrata., 2004).
Dari data hasil menunjukkan pemeriksaan golongan darah menggunakan serum sebagai reagen pada golongan darah A didapatkan hasil positif pada jenis kelamin laki-laki 16 orang sedangkan jenis kelamin perempuan 9 orang. Golongan darah B didapatkan hasil positif pada jenis kelamin laki-laki 26 orang sedangkan jenis kelamin perempuan 18 orang. Golongan darah AB didapatkan hasil positif pada jenis kelamin laki-laki 10 orang sedangkan jenis kelamin perempuan 12 orang, kemudian Golongan darah $\mathrm{O}$ didapatkan hasil positif pada jenis kelamin laki-laki 14 orang sedangkan jenis kelamin perempuan 19 orang.

Berdasarkan reaksi antigen-antibodi yanng berada di dalam serum maka serum A, B dan O dapat dijadikan sebagai reagen anti $\mathrm{A}$, anti $\mathrm{B}$, dan anti $\mathrm{AB}$ dalam menentukan golongan darah. Namun berdasarkan analisis data, kualitas penggumpalan yang dihasilkan oleh serum tidak sama dengan aglutinasi yang dihasilkan oleh reagen anti $\mathrm{A}$, anti $\mathrm{B}$, dan anti $\mathrm{AB}$ dalam menentukan golongan darah. Penggumpalan yang terjadi tidak sejelas pada reagen kontrol. Namun pada golongan darah $\mathrm{O}$ semua serum memberikan hasil yang sama dengan reagen kontrol yaitu tidak ada penggumpalan yang terjadi (Sindu, 2002). 


\section{KESIMPULAN}

Dari hasil pemeriksaan dapat disimpulkan bahwa pemeriksaan golongan darah golongan darah A didapatkan hasil positif pada jenis kelamin laki-laki 16 orang sedangkan jenis kelamin perempuan 9 orang. Golongan darah B didapatkan hasil positif pada jenis kelamin laki-laki 26 orang sedangkan jenis kelamin perempuan 18 orang. Golongan darah AB didapatkan hasil positif pada jenis kelamin laki-laki 10 orang sedangkan jenis kelamin perempuan 12 orang, kemudian Golongan darah $\mathrm{O}$ didapatkan hasil positif pada jenis kelamin laki-laki 14 orang sedangkan jenis kelamin perempuan 19 orang

\section{DAFTAR PUSTAKA}

Basak A. 2014. Frequency Distribution of ABO Blood Group and Rh Factor among the Local Domiciles of East Midnapore District, West Bengal. 5:273-276.

Dacie S.J.V., Lewis. S.m., 1984. Practical Haematology, 6th ED. New York: Churchill Livingstone. 337-357.

Eweidah MH, Rahiman S, Ali H. 2011. Distribution of $\mathrm{ABO}$ and Rhesus ( RHD ) Blood Groups in Al-Jouf Province of the Saudi Arabia. 13:99102.

Fitri.2007. Manfaat Mengetahui Golongan Darah. http://www.wikimu.com.
Gandasoebrata R. 2004. Penuntun Laboratorium Klinik. Dian Rakyat. Jakarta

Glinka, J. 2008. Variasi Distribusi Golongan Darah ABO. dalamManusia Makhluk Sosial Biologis. (M. Dyah Artaria, Ed.). Surabaya: Airlangga University Press.

Guyton, Arthur C. 1997. Buku Ajar Fisiologi Kedokteran. Edisi V. EGC. Jakarta

Hosseini $\quad$ B. 2007. Genetic Characterisation of Human $A B O$ Blood Group Variants with a Focus on Subgroups and Hybrid Alleles. Swedia: Lund University.

Sasmita Chandra. 2008. Pengenalan Golongan Darah. FT UI.

Sindu,Ellyani. 2002. Immunohematologi dan Sistim Golongan Darah. Depkes RI, Jakarta

Sudiono. S., Hertian. ., Winardi. T., Penentuan Golongan Darah. FK-UI : Jakarta 